Original Paper

\title{
Workshop Penelitian Tindakan Kelas (PTK) Inovatif Bagi Guru SMAN 1 Kopang Lombok Tengah
}

\author{
Asrin $^{1 *}$, I Wayan Karta1, Untung Waluyo', Muntari ${ }^{1}$ \\ ${ }^{1}$ Program Studi Magister Administrasi Pendidikan, Pascasarjana Universitas Mataram, Indonesia.
}

DOI: $10.29303 /$ jpmpi.v3i1.417

Sitasi: Asrin, A., Karta, I., Waluyo, U., \& Muntari, M. (2020). Workshop Penelitian Tindakan Kelas (PTK) Inovatif Bagi Guru SMAN 1 Kopang Lombok Tengah. Jurnal Pengabdian Magister Pendidikan IPA, 3(1). doi:https://doi.org/10.29303/jpmpi.v3i1.417

*Corresponding Author: Asrin, Program Studi Magister Administrasi Pendidikan, Pascasarjana Universitas Mataram, Indonesia;

Email:

bajangasrin@gmail.com

\begin{abstract}
Abstrak: Pengembangan mutu guru merupakan salah satu strategi meningkatkan mutu pendidikan di sekolah. Guru membutuhkan kompetensi pedagogik, sosial, keperibadian dan profesionalisme untuk selalu terus menerus meningkatkan kinerja dan produktivitas dalam pembelajaran. Mutu guru perlu selalu diupayakan agar terjadi peningkatan mutu secara signifikan.Tugas dan fungsi guru yang sangat penting untuk meningkatkan kualitas pembelajaran di sekolah. Kompetensi profesional guru dapat terus berkembang melalui peningkatan pendidikan dan pelatihan secara terencana dan terprogram. Kompetensi guru yang membutuhkan peningkatan agar guru dapat mengembangakan penelitian tindakan kelas.Penelitian ini bertujuan untuk mengembangkan kemamapuan guru untuk mengembangkan inovasiinovasi pembelajaran di sekolah. Peningkatan kompetensi guru dalam melakukan penelitian hingga dapat menganalisis dan mencari pemecahan masalah terhadap masalah-masalah pemeberlajaran yang dihadapi guru di kelas. Melalui workshop ini diharapkan para guru telah memiiliki peningkatan kompetensi dalam melaksanakan, menemukan, dan menerapkan inovasi pembelajaran di ruang kelas. Pelaksanaan kegiatan Workshop PTK ini telah dilaksanakan di SMAN 1 Kopang Kabupaten Lombok Tengah yang diikuti oleh 40 guru. Pada kegiatan diberikan konsep tentang dan pelaksanaan PTK di sekolah untuk meningkatkan perbaikan dan inovasi pembelajaran di sekolah. Guru dapat menyusun proposal PTK dana sekaligus melakukan penelitian terkait pemebelajaran. Untuk itulah dalam rangka meningkatkan kompetensi guru ini, maka telah dilakukan Workshop Penelitian Tindakan Kelas bagi guru-guru SMAN 1 Kopang sebagai upaya pengembangan tugas Pascasarjana Prodi Administrasi Pendidikan pada Tahun Anggaran 2019 dari DIPA-BLU (PNBP) Universitas Mataram.
\end{abstract}

Kata Kunci: Workshop; Penelitian Tindakan Kelas; Inovatif.

\section{Pendahuluan}

Diberlakukannya Undang-undang RI Nomor 14 Tahun 2005 tentang Guru dan Dosen, merupakan bukti pengakuan terhadap profesionalitas pekerjaan guru dan dosen semakin mantap. Terlebih lagi di dalam pasal 14 dan 15 Undang-undang tersebut dinyatakan bahwa guru berhak memperoleh penghasilan di atas kebutuhan hidup minimum dan jaminan kesejahteraan sosial, meliputi gaji pokok, tunjangan yang melekat 
pada gaji, serta penghasilan lain berupa tunjangan profesi, tunjangan fungsional, tunjangan khusus, dan maslahat tambahan yang terkait dengan tugasnya sebagai guru yang ditetapkan dengan prinsip penghargaan atas dasar prestasi.

Bagi para guru pengakuan dan penghargaan di atas harus dijawab dengan meningkatkan profesionalisme dalam bekerja. Guru tidak selayaknya bekerja as usual seperti era sebelumnya, melainkan harus menunjukkan komitmen dan tanggung jawab yang tinggi (Jannah, 2014). Setiap kinerjanya harus dapat dipertanggung jawabkan baik secara publik maupun akademik (Naro, 2017). Untuk itu guru harus memiliki landasan teoretik atau keilmuan yang mapan dalam melaksanakan tugasnya mengajar maupun membimbing peserta didik.

Dalam kegiatan pembelajaran, seorang guru sudah pasti akan berhadapan dengan berbagai persoalan baik menyangkut peserta didik, subject matter, maupun metode pembelajaran. Sebagai seorang profesional, guru harus mampu membuat prefessional judgement yang didasarkan pada data sekaligus teori yang akurat (Osnal, 2016). Selain itu guru juga harus melakukan peningkatan mutu pembelajaran secara terus menerus agar prestasi belajar peserta didik optimal (Wafa, 2017). Untuk mewujudkan hal tersebut guru harus dibekali dengan kemampuan meneliti, khususnya Penelitian Tindakan Kelas.

Peran pengawas sebagai pembina dan pembimbing guru tentu sangat dibutuhkan, hal ini sesuai dengan Permendiknas no. 12 tahun 2007 tentang Standar Pengawas Sekolah/Madrasah. Pengawas tidak hanya berperan sebagai resources person atau konsultan, bahkan dapat secara kolaboratif bersama-sama dengan guru melakukan penelitian tindakan kelas bagi peningkatan pembelajaran. Dengan catatan permasalahan yang diangkat adalah persoalan guru dalam proses pembelajarannya.

Dewasa ini, dengan adanya sertifikasi guru para pendidik dituntut untuk mampu meneliti. Tuntutan agar guru mampu meneliti semakin gencar dilakukan oleh pemerintah. Hal itu dibuktikan dari laporan portofolio guru yang mensyaratkan melampirkan karya tulisnya dalam sertifikasi guru dalam jabatan karena hal itulah maka guru-guru di sekolah harus dapat meneliti di kelasnya sendiri dengan tujuan memperbaiki kualitas pembelajarannya melalui Penelitian Tindakan Kelas (PTK). PTK sesungguhnya merupakan implementasi dari kreativitas dan kekritisan seorang guru terhadap apa yang sehari-hari diamati dan dialaminya sehubungan dengan profesinya untuk menghasilkan kualitas pembelajaran yang lebih baik sehingga mencapai hasil belajar yang optimal (Anggraeni \& Nurani, 2017).

Namun, sangat disayangkan masih banyak guru-guru yang belum mengenal dan belum melakukan PTK sama sekali di kelasnya Sehingga tujuan dari worshop ini adalah mengajak atau memotivasi guru yang masih enggan mengadakan penelitian karena berbagai alasan untuk dapat mengembangkan potensi siswa yang ada di kelasnya. Dengan mengetahui potensi siswa, guru menjadi semakin dekat dengan para siswanya, dan terjadilah proses interaktif di antara guru dan siswa.

Workshop ini juga mengajak temanteman guru untuk melangkah kepada berbagai catatan yang setelah diolah dapat mewujud menjadi suatu penelitian yang berkualitas. Melaksanakan penelitian tentang apa yang sehari-hari dilakukan oleh seorang guru yang akhirnya dapat menghasilkan suatu karya yang disebut PTK. Hal itu dapat terjadi apabila suatu urutan umum prosedur, yaitu bermula dari identifikasi masalah penelitian yang dihadapi sampai dengan laporan hasil akhirnya dicatat. Jadi, amat penting suatu prosedur ini dipahami dan ditaati oleh guru yang meneliti.

Penelitian di bidang pendidikan memang memerlukan sejumlah instrumen yang terdiri dari berbagai pendekatan untuk mengkaji berbagai isu pendidikan dalam masyarakat kita. Tidak cukup pendidikan 
formal membatasi diri pada eksperimen atau penelitian yang hanya berkenaan dengan kurikulum ataupun masalah-masalah yang terungkap dalam buku pelajaran. Seharusnya praktek pendidikan lebih menerobos kepada kehidupan nyata, mengajak peserta didik, untuk tidak saja berpikir pada kala ia belajar, tetapi lebih banyak belajar untuk berpikir lebih dalam tentang berbagai masalah dalam kehidupan ataupun lingkungan sekitar. Melalui berbagai cara yang telah dipaparkan, berbagai masalah itu akan membuka pikiran kita dalam menemukan berbagai solusi untuk mengatasi berbagai kesenjangan masalah pembelajaran.

Dengan memahami dan memperhatikan karakteristik setiap siswa, maka guru dapat mengembangkan potensi unik yang dimiliki oleh setiap siswa dengan melakukan berbagai tindakan yang terhimpun ke dalam sebuah penelitian tindakan kelas (PTK). Melalui PTK yang dirancang guru, para guru diharapkan dapat menemukan potensi unik siswa yang berujung kepada peningkatan hasil belajar.

Berdasarkan hal tersebut di atas, maka kami bersama Bapak/ibu Fasilitator yang berpengalaman dalam Penelitian untuk melakukan suatu kegiatan workshop PTK yang mengajak para guru untuk aktif menulis, meneliti dan menuliskan laporan penelitiannya sehingga dapat meningkatkan kualitas pembelajarannya di kelas.Disamping materi PTK kami suguhkan materi pendukung yaitu model -model pembelajaran inovatif dan Pengembangan Keprofesiaan Berkelanjutan (PKB) yang tdk terpisahkan dengan PTK itu sendiri.Dengan latar belakang di atas, maka materi pelatihan penelitian tindakan kelas ini sangat penting untuk dikuasai oleh para guru.

\section{Metode Pelaksanaan}

Sasaran dalam kegiatan pelatihan Pendekatan yang akan digunakan dalam kegiatan pengabdian ini dengan kegiatan berupa workshop yang lebih berbasis pada praktek langsung dan pembimbingan bersifat mentoring oleh tim pengabdian. Para guru diberikan pembekalan lebih dahulu pemahaman tentang penelitian tindakan kelas (PTK). Para guru melakukan praktek langsung mengembangkankan dengan membuat proposal yang sudah disiapkan sebelum workshop berlangsung. Para guru disyaratkan membawa proposal awal tentang PTK, yang kemudian dinilai dan direvisi oleh Tim Pengabdiam. Proposal yang dibuat para guru diberikan kelinik proposal untuk memperbaiki sehinga benar-benar sesaui dengan standar PTK yang diharapkan. Setelah itu kembali dikumpulkan dan direview apa yang sudah dibuat oleh guru tersebut, kemudian diberikan penjelasan atau perbaikan-perbaikan proposal.

Kegiatan workshop ini merupakan upaya untuk memberikan pengetahuan dan keterampilan untuk melakukan membuat proposal PTK dan melaksanakan penelitian PTK di SMAN 1 Kopang Lombok Tengah. Sehingga pada kegiatan pengabdian ini mengutamakan tercapainya target di mana masing-masing peserta dapat memiliki proposal penelitian, yang akan dilakukan pada proses pembelajaran di kelas.

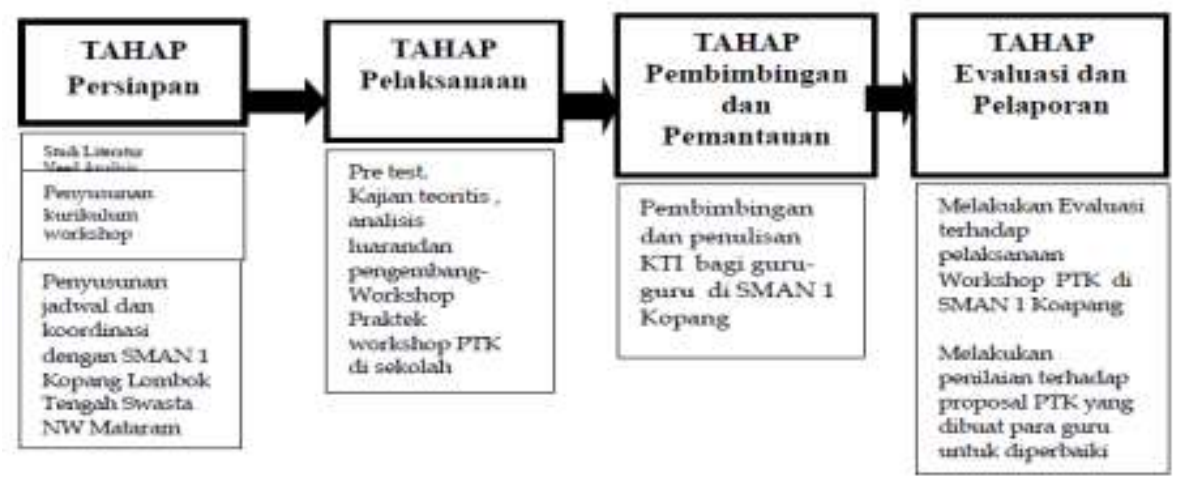

Gambar 1 Tahapan Pelaksanaan Kegiatan Pengabdian 


\section{Hasil dan Pembahasan}

\section{A. Persiapan}

\section{Penyusunan Proposal Pengangabdian}

Sebelum pengabdian dimulai maka time pengabdian terlebh dahulu membuat proposal pengabdian dan mendapatkan kesimpulan untuk melaksanakan PTK di SMAN 1 Kopang. Pelatihan ini membantu guru unutk memperbaiki pengetahuan dan keterampilannya. Penyususnan proposal Workshop PTK ini dapat menjadi bagian utama dari menyiapkan pelaksanaan pengabdian pada masyarakat di SMAN 1 Koapang Lombok Tengah.

Pada kegiatan penyususn proposal ini Tima Peneliti melakuakan FGD untuk menyatukan rencana kegiatan pengabdian yang dilaksnakan di SMAN 1 Koapang. Pada saat penyusuanan proposal ini terlebih dahulu juga telah membangun komunikasi dengan pihak Kepala Sekolah SMA 1 Kopang untuk memastikan kesiapan para guru menjadi perserta pelatihan. Di samping itu juga antara TIM Peneliti dan SMAN 1 Kopang telah menjadi sekolah mitra yang menyiapkan fasilitas aula sekolah sebagai tempat pelatihan berlangsung. Menetapkan jadwal kegiatan dan skenario kegiatan Workshop PTK secara lebih detail/rinci sebagiaman untuk meningkatkan mutu pendidikan.

\section{Kajian Teoritis PTK dan Mendisain Kurikulum}

Pengembangan kemampuan meneliti dan menulis guru di sekolah menengah merupakan kebutuhan mutlak untuk meningkatkan mutu pendidikan di sekolah. Salah satu kompetensi yang harus dimiliki guru adalah mengingkatkan kemampuan meneliti dengan pendekatanan Penelitian Tindakan Kelas (PTK) untuk memperdalam profesionalisme dalam praktik pembelajaran di kelas. PTK sebagai salah satu upaya untuk meningkatkan kemampuan guru memecahkan masalah-masalah praktis pemebelajaran yang dihadapinya. PTK merupakan alternatif untuk meningkatkan perbaikan pembelajaran di kelas,

Pengembangan profesionalitas guru ke depan menjadi salah satu faktor utama bagi peningkatan kualitas pendidikan di segala jenis dan jenjang pendidikan. Bahkan pengambangan guru dapat menjadi bagian yang ditingkatkan pada tingkat sekolah. Pada saat yang sama kebutuhan untuk meningkatkan mutu guru dalam pelaksanaan penelitian tindakan kelas sebagai upaya memperbaiki kualtas pendidikan. Hal ini dapat menjadi sangat penting bagi peningkatan keterampilan guru untuk memahami dan memecahkan masalah pembelajaran di kelas.

PTK dapat menjadi bagian utama untuk memperbaiki dan meningkatkan profesionalitas guru agar dapat menciptakan pembelajaran yang lebih efektif, Guru dapat melakukan pemahaman masalah-masalah pembelajaran yang lebih terbaru terkait dengan perkembangan kurikulum pendidiikan, model pembelajaran, media pembelajaran, dan lain-lainnya. PTK menjagi sangat dibutuhkan guru juga untuk memenuhi kebutuhan karya ilmiah sebagai persyaratan untuk mengajukan kenaikan kepangkatan lebih tinggi.

PTK sangat penting bagi guru sekolah karena: 1) Untuk memecahkan masalahmasalah yang ada di dalam kelas; 2) Untuk memperbaiki mutu pembelajaran di kelas; 3) Untuk mencermati setiap upaya atau tindakan yang dilalukan guru di kelas; 4) untuk menerapkan metode-metode terbagu dalam pembelajaran di kelas: 4) untuk mengembangkan inovasi pembelajaran di kelas dari segi penggunaan media, model dan strategi pembelajaran yang sesuai dengan perkembangan ilmu pengetahauan, budaya dan teknologi.

Tahapan Pelaksanan Penelitian Tindakan Kelas (PTK) adalah: 1) Tahap 1; Menyususn rencana. Dalam menyusun rencana ini guru menentukan titik fokus kegiatan atau peristiwa yang akan diamati 
seperti perilaku anak-anak yang bermain, perkembangan berbahasa anak. 2) Tahap 2: Pelaksanaan Tindakan. Pada tahapan ini bahwa peneliti berupaya untuk melaksanakan isi rancangan yang sudah dipersiapkan peneliti (guru/kepaka sekolah). 3) Tahap 3: Pengamatan. Pada tahap ini guru atau kepala sekolah mengamati tindakan yang terjadi serta memperbaikinya pada siklus berikutnya. 4) Tahap 4: Refleksi. Pada tahap ini peneliti (guru/kepala sekolah) melakukan refleksi dari pengamatan dan pengumpulandata kemudian muncul permasalahan baru sebagai hasil refleksi. Masalah yang muncul kemudian dipecahkan pada siklus berikutnya.

\section{Analisis Kebutuhan Guru Workshop PTK}

Berdasarakan hasil observasi awal bahwa SMAN 1 Kopang memiliki upaya untuk meningkatkan pengembangan kompetensi PTK guru. Masih rendahnya kemampuan menulis guru dapat menjadi kebutuhan utama untuk meningkatkan kualitas pendidikan. Kemampuan untuk membangun pendidikan. Pada saat yang sama bahwa kebutuhan guru SMAN 1 Kopang dilakukan sangat tinggi untuk mengembangkan komptensi penelitian para guru.

Kepala Sekolah SMAN 1 Kopang memiliki perencanaan dan programa kegiatan untuk meningkatkan kualitas gutu dari tahun ke tahuan. Hal ini disadari bahwa guru memiliki peran penting dalam meningkatkan mutu pembelajaran di kelas. Kompetensi guru dalam merancang pembelajaran hingga melakukan inovasi dapat mendukung keefektifan pelaksanaan pembelajaran agar mencapai tujuan dan target yang tepat.

Ketika melakukan diskusi awal dengan kepala sekolah SMAN 1 Kopang bahwa kegiatan ini sangat dibutuhkan oleh guru dalam rangka menigkatkan kualitas guru untuk melakukan pembelajaran di kelas. Kepala sekolah sangat merespon positif kegiatan yang dilakukan Prodi Magister Administrasi Pendidikan Universitas Mataram ini, dalam rangka meningkatkan kompetensi guru dalam melakukan penelitian dan inovasi pembelajaran di sekolah.

Jumlah Guru yang ikut berperanserta pada Workshop PTK sebanyak 40 orang guru sesuai dengan rencana awalnya. Kepala sekolah mengakui bahwa kemampuan dan semamgat meneliti guru SMAN 1 Kopang masih sangat rendah. Untuk itulah dengan melakukan pelatihan ini diharpakan guru memiliki keterampilan dan semangat untuk menulis PTK.

\section{B. Pelaksanaan Workshop PTK}

Pelaksanaan Workshop PTK SMAN 1 Kopang merupakan Pengabdian Pada Masyarakat Program Studi Magister Administrasi Pendidikan Pascasarajan Universitas Mataram. Kegiatan berawal ini berlangsung atas kerja sama Pasca sarjana Unram dengan Pihak SMAN 1 Kopang dalam rangka meningkatkan kapasitas dan kompetensi guru sekolah untuk melakukan penelitian di sekolah.

Pelaksanaan Workshop PTK bertujuan untuk mengembangkan kompetensi guru dalam penelitian baik pendekatan kualitatif dan kuatitatif. Sehingga kurikulum dirancang agar untuk memberikan kompetensi dasar bagi guruSMAN 1 Kopang meliputi sebagai berikut; : 1) Penelitian Pendidikan dan Penelitian Tindakan Kelas; 2) Pendekatan Kualitatif Pada Penelitian Tindakan Kelas; 3)Pendekatan Kuantitatif Pada Penelitian Tindakan Kelas; 4) Penulisan Karya Tulis Ilmiah Untuk Jurnal Terakreditas; 5) Pembuatan Proposal Penelitian Tindakan Kelas.

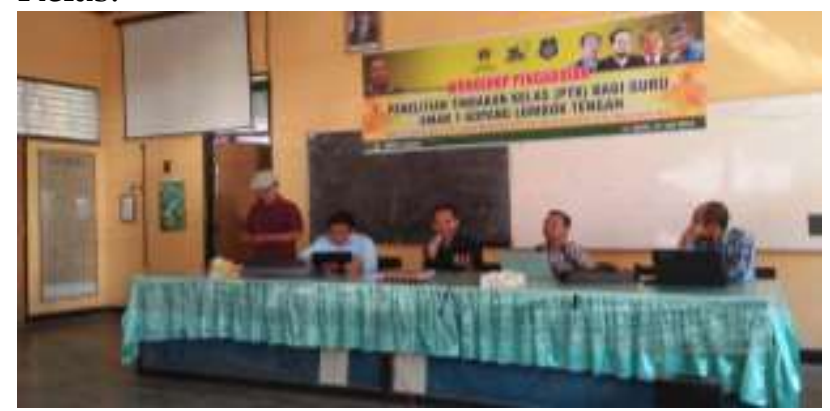

Gambar 1. Penyampaian Kata Sambutan Kegiatan Workshop 


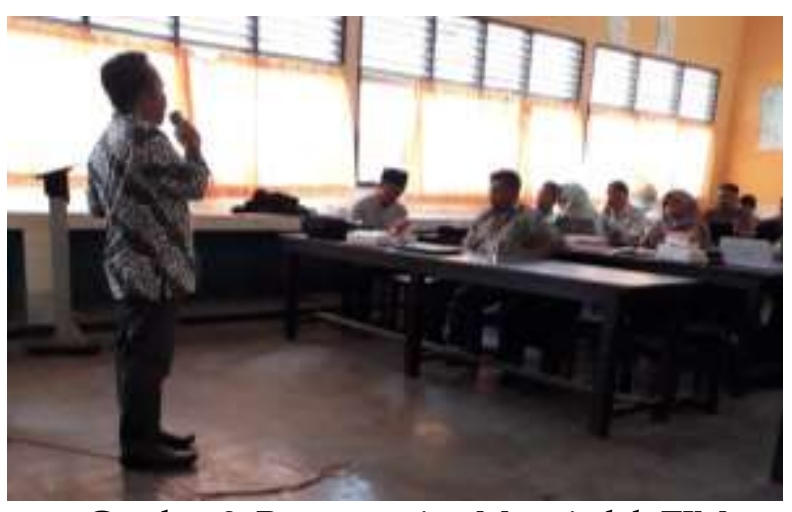

Gambar 2: Penyampaian Materi oleh TIM

Adapun pemateri dari kegiatan workshop ini adalah Dr. Wayan Karte, M.Pd., Dr. Muntari, Phil., Dr. Asrin, M.Pd., Drs. Untung Waluyo, P.hD., dan Dr. Dian Iskandar Jaelani, M.A.

\section{Kesimpulan}

Kegiatan pengabdian kepada
masyarakat ini dibuat dalam bentuk Workshop atau pelatihan Penelitian Tindakan Kelas (PTK). Workshop ini mengajak temanteman guru untuk melangkah kepada berbagai catatan yang setelah diolah dapat terwujud menjadi suatu penelitian yang berkualitas. Melaksanakan penelitian tentang apa yang sehari-hari dilakukan oleh seorang guru yang akhirnya dapat menghasilkan suatu karya yang disebut PTK. Melalui PTK yang dirancang guru, para guru diharapkan dapat menemukan potensi unik siswa yang berujung kepada peningkatan hasil belajar. Adapun kegiatan ini mengajak para guru untuk aktif menulis, meneliti dan menuliskan laporan penelitiannya sehingga dapat meningkatkan kualitas pembelajaran di kelas. Di samping materi PTK yang kami suguhkan materi pendukung yaitu model-model pembelajaran inovatif dan Pengembangan Keprofesian Berkelanjutan (PKB) yang tidak terpisahkan dengan PTK itu sendiri.

Hasil Kegiatan ini antara lain untuk mengembangkan kompetensi guru dalam penelitian baik pendekatan kualitatif dan kuatitatif.Sehingga kurikulum dirancang agar untuk memberikan kompetensi dasar bagi
guruSMAN 1 Kopang meliputi: 1) Penelitian Pendidikan dan Penelitian Tindakan Kelas; 2) Pendekatan Kualitatif Pada Penelitian Tindakan Kelas; 3)Pendekatan Kuantitatif Pada Penelitian Tindakan Kelas; 4) Penulisan Karya Tulis Ilmiah Untuk Jurnal Terakreditas; 5) Pembuatan Proposal Penelitian Tindakan Kelas.

\section{Ucapan Terimakasih}

Ucapan terimakasih kami sampaikan kepada kepada Universitas Mataram melalui Lembaga Penelitian dan Pengabdian Kepada Masyarakat yang telah memberi dukungan financial terhadap kegiatan Pengabdian ini.

\section{Daftar Pustaka}

Anggraeni, A.D. dan Nurani, S. (2018). Penyusunan Proposal Penelitian Tindakan Kelas (PTK) Pada Guru-Guru Sekolah Yayasan Kholifah Masa Depan Depok. Jurnal PKM: Pengabdian kepada Masyarakat. 1(3). 199-204

Jannah, W. (2014). Komitmen Guru dalam Melaksanakan Tugas di Sekolah Menengah Atas (SMSA) Kecamatan Rokan IV Koto. Jurnal Administrasi Pendidikan, 2(1). 789 - 831

Naro, W. (2017). Komitmen Profesi dan Pengaruhnya Terhadap Kompetensi Profesional Guru Pada Madrasah Tsanawiyah Di Kota Makassar. Jurnal Inspiratif Pendidikan. VI(1). 35-58

Osnal. (2016). Upaya Meningkatkan Motivasi Dan Kompetensi Guru Kelas 4, Kelas 5, Dan Kelas 6 Dalam Menyusun Proposal Ptk Melalui Bimbingan Kelompok Di KKG Gugus 6 Kecamatan Sumbermalang Kabupaten Situbondo Semester 2 Tahun Pelajaran 2015/2016. Pancaran, 5(4), 61-78.

Undang-Undang Guru dan Dosen, 2007. Kemnediknas. Jakarta

Wafa, A. (2017). Peningkatan Mutu Pembelajaran Berbasis Aneka Sumber 
Asrin et al, Jurnal Pengabdian Magister Pendidikan IPA 2020, (3) 1 : 8-14

e-ISSN: 2655-5263

Belajar Di MTsN Sumber Bungur

Pamekasan. Kabilah. 2(2), 237-253 